\title{
VIRGÍLIO TRADUZIDO NO BRASIL: ANÁLISE DOS PREFÁCIOS E NOTAS DOS TRADUTORES
}

\author{
Thaís Fernandes 1 \\ ${ }^{1}$ Universidade Federal de Santa Catarina, Florianópolis, Santa Catarina, Brasil
}

\begin{abstract}
Resumo: Este artigo apresenta as traduções das três obras de Virgílio, Geórgicas, Bucólicas e Eneida, publicadas no Brasil entre 1808 e 2016. Os prefácios e as notas dessas obras, quando escritos por seus respectivos tradutores, foram analisados a partir da teoria dos paratextos, desenvolvida por Genette. Por meio dessa análise, quatro temas foram identificados como mais recorrentes: contextualização da obra e seu autor; problemas e especificidades da tradução; diálogo entre tradutores; e justificativas para o projeto de tradução. Para exemplificar como os tradutores tratam cada um desses temas, foram selecionados exemplos de seus discursos, presentes nos prefácios e notas analisados. Por fim, a análise revelou a importância desses paratextos para a leitura e compreensão das obras de Virgílio pelos leitores de hoje.

Palavras-chave: História da Tradução no Brasil; Literatura Clássica Latina; Virgílio; Paratextos
\end{abstract}

\section{VIRGIL TRANSLATED IN BRAZIL: ANALYSIS OF PREFACES AND NOTES FROM THE TRANSLATORS}

\begin{abstract}
This paper presents the translations of the three poems of Virgil, the Georgics, the Eclogues and the Aeneid, published in Brazil between 1808 and 2016. The prefaces and notes of these works, when written by their respective translators, were analyzed based on the paratexts theory developed by Genette. Through this analysis, four themes were identified as more recurrent: contextualization of the work and its author; problems and specificities of the translation; dialogue between the translators; and justifications for the translation project. To exemplify how translators deal with each of these themes, examples were extracted from the prefaces
\end{abstract}


and notes and subsequently analyzed. Finally, the analysis revealed the importance of these paratexts for the reading and understanding of Virgil's works by today's readers.

Keywords: Translation History in Brazil; Classical Latin Literature; Virgil; Paratexts

Virgílio (70-19 a.C.) foi autor de três obras fundamentais para a literatura Ocidental: Bucólicas (publicada por volta de 39 a.C.), Geórgicas (concluída em 29 a.C.) e Eneida (publicada após sua morte em 19 a.C.). O presente estudo objetiva apresentar uma análise das traduções dessas obras publicadas no Brasil, em livro impresso, de $1808^{1}$ até 2016. Mais especificamente, examinamos os prefácios e as notas dessas traduções, quando escritos por seus respectivos tradutores, a partir da teoria dos paratextos desenvolvida por Genette. A análise buscou revelar se há, nos prefácios e notas, alguma reflexão sobre problemas de tradução e quais são eles.

A literatura traduzida tem papel fundamental na formação e na renovação das literaturas nacionais. No Brasil, apesar do empenho recente de pesquisadores da área dos Estudos da Tradução, há um longo caminho a percorrer para que tenhamos uma história, ainda que incompleta, da literatura traduzida no país. Para Torres, " [...] elaborar uma história da tradução não significa necessariamente, como a idealizamos no Brasil até agora, criar uma obra sintética, a mais exaustiva possível, [...] mas sim, no caso específico do Brasil, significa produzir uma ou mais micro-história(s) de tradução." (Torres Democratização de arquivos em bibliotecas digitais e hemerotecas: um caminho para Histórias ou Micro Histórias da tradução no Brasil, 211). Ao retomar o conceito de micro-história ${ }^{2}$, Torres defende o estudo de fenômenos particulares, o que levaria à formulação de hipóteses mais gerais em um momento posterior. A partir dessa perspectiva, esta pesquisa busca contribuir para o

${ }^{1}$ Escolhemos a data de 1808 como início para o período analisado por ser o ano da instalação da Impressão Régia (Hallewell 111).

${ }^{2}$ Torres refere-se ao conceito desenvolvido por autores italianos como Carlo Ginzburg, Edoardo Grendi, Giovanni Levi e Carlo Poni. 
conhecimento da história da literatura traduzida no Brasil, trazendo à tona uma parte do seu conjunto.

No âmbito da área dos Estudos Clássicos, pesquisadores brasileiros também vêm salientando a necessidade do mapeamento das traduções gregas e latinas. Como afirma Duarte, "a história da tradução dos clássicos greco-latinos no Brasil ainda está por ser escrita" (43). Além de contribuir para a ampliação dessa história, esta pesquisa intenta valorizar o trabalho de tradutores que tanto contribuíram para a formação da literatura nacional, resgatando-os do passado como "[...] autênticos protagonistas, sujeitos históricos da tradução, muitas vezes anônimos." (Pinilla 231).

Fundamentam teoricamente este estudo a teoria dos polissistemas, pensada por Even-Zohar, e a mencionada teoria dos paratextos, desenvolvida por Genette. A teoria dos polissistemas permite-nos descrever as traduções no contexto da literatura de chegada, ou seja, a literatura latina traduzida no contexto brasileiro, pensando a tradução como parte do sistema literário nacional. Even-Zohar entende a literatura como um polissistema, uma estrutura aberta e dinâmica, constantemente modificada pelas relações entre os vários sistemas que o compõem. Para esse autor, a tradução tem um papel fundamental nos sistemas literários nacionais, pois a literatura traduzida não é somente um sistema presente em outro sistema literário mas, em alguns casos, o mais ativo entre eles, sendo responsável por grande parte das inovações presentes na literatura nacional.

Já os paratextos são compreendidos como espaços de visibilidade do tradutor, a partir da noção de invisibilidade proposta por Venuti. Genette explica que o texto literário raramente se apresenta isolado de

[...] certo número de produções, verbais ou não, como um nome de autor, um título, um prefácio, ilustrações, que nunca sabemos se devemos ou não considerar parte dele, mas que em todo caso o cercam e o prolongam, exatamente para apresentá-lo, no sentido habitual do verbo, mas também em seu sentido mais forte: para torná-lo presente, para garantir 
sua presença no mundo, sua 'recepção' e seu consumo, sob a forma, pelo menos hoje, de um livro. (Genette 9).

Esses elementos que o acompanham são conceituados pelo autor como paratextos, que possuem extensão e características diversas, dependendo da data, do local e de outros fatores de publicação da obra. Genette distingue dois tipos de prefácio: o prefácio alógrafo, aquele que não é escrito pelo autor do texto, e o prefácio autoral, ou autógrafo, escrito pelo autor do texto. No caso da tradução, “[...] o prefácio pode ser [...] assinado pelo tradutor. O tradutor-prefaciador pode eventualmente comentar (entre outras coisas) sua própria tradução; neste caso e neste sentido, seu prefácio deixa então de ser alógrafo" (Genette 233), ou seja, o tradutor passa a ser autor quando comenta sobre seu próprio texto: a tradução.

Sobre as notas, Genette afirma: "uma nota é um enunciado de tamanho variável (basta uma palavra) relativo a um segmento mais ou menos determinado de um texto, e disposto seja em frente seja como referência a esse segmento." (Genette 281). Assim como os prefácios, as notas também podem ser autográficas ou alográficas (Genette 284-285). Se usarmos o mesmo critério de distinção dos prefácios, as notas do tradutor que se limitam a comentar o texto seriam alográficas, ao passo que aquelas em que o tradutor se posiciona ou explica algo seriam autográficas. Sobre essa distinção, Soto (78-79) chama a atenção para o fato de que o tradutor anota o próprio texto e, neste caso, poder-se-ia questionar o estatuto alográfico dessas notas. Para Soto, as notas do tradutor "[...] podem desde ocupar uma posição textual marginal (autográficas) até terem um estatuto claramente paratextual (alográficas)", isto é, “[...] notas autográficas seriam as aclaratórias (ou seja, aquelas que explicam o termo anotado, em outras palavras) [...]" e “[...] notas alográficas são aquelas que ponderam sobre o texto mencionando o autor do original como avalista do comentário." (Soto 78). Em relação a essa discussão, nossa compreensão é a de que as notas do tradutor são autográficas, pois é ele quem escolhe como e o que anotar, sendo o autor do texto das notas. 
Em prefácio a Traduzir o Brasil literário, de Marie-Hélène Torres, Germana Henriques Pereira de Souza afirmam que os paratextos

\begin{abstract}
[...] e molduram a obra traduzida e garantem um espaço de visibilidade à voz do tradutor, mas não só, os discursos de acompanhamento ancoram a obra no horizonte da crítica literária e definem parâmetros que conduzirão à leitura e recepção do texto traduzido [...]. (Souza 12).
\end{abstract}

Nesse sentido, os prefácios e notas são elementos em que se reserva ao tradutor o direito à palavra e ele deixa de ser invisível. A noção de invisibilidade do tradutor, como pensada por Venuti, manifesta-se em dois fenômenos: por um lado, os leitores quase sempre leem um texto traduzido como se tivesse sido escrito em sua própria língua; de outro, quanto mais uma tradução é fluente, mais ela é aceita. Esse apagamento resulta numa invisibilidade social e textual.

Para diminuir a invisibilidade dos tradutores, Venuti defende uma tradução estrangeirizadora - na qual o tradutor recupera traços linguísticos, literários e culturais do texto original -, em oposição a uma tradução domesticadora - na qual o tradutor procura apagar estranhezas produzidas pelas diferenças entre as línguas para que o texto da tradução se torne mais fluente. Os prefácios escritos pelos tradutores também são considerados por Venuti espaços em que podem se fazer visíveis, tirando do leitor a impressão de estar lendo um texto original. Nessa perspectiva, pensamos que as notas podem se comportar da mesma forma, pois nelas o tradutor comenta sua prática, expõe sua interpretação e amplia o conhecimento do leitor ao apresentar informações sobre autor e obra traduzidos.

A análise dos paratextos foi motivada pelo método desenvolvido por Carneiro em sua tese a respeito dos prefácios de traduções de obras francesas. Embora o método de Carneiro tenha sido pensado para os prefácios, a partir dele foi possível analisar também as notas. A autora identificou na sua análise uma série de movimentos 


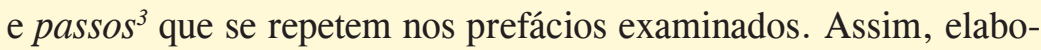
ramos uma lista de temas que apareceram com mais frequência nos prefácios e notas dos tradutores de Virgílio: contextualização da obra e seu autor; problemas e especificidades da tradução; diálogo entre tradutores; e justificativas para o projeto de tradução.

Para obter essa lista, primeiramente, buscamos as traduções disponíveis no catálogo on-line da Biblioteca Nacional. Também consultamos outras fontes ${ }^{4}$ com o intuito de conferir as informações encontradas. Posteriormente, examinamos os livros físicos disponíveis na Biblioteca Nacional para cotejar as informações obtidas e analisar prefácios e notas ${ }^{5}$.

${ }^{3}$ Carneiro, em sua tese, identificou a seguinte série no corpus por ela analisado:

MOVIMENTO 1 - APRESENTAÇÃO DA EDIÇÃO

MOVIMENTO 2 - BIOGRAFIA DO(S) AUTOR(ES)

Passo 2A - Fatos histórico-biográficos

Passo 2B - Escola literária de pertencimento

Passo 2C - Fontes e influências

MOVIMENTO 3 - O CONJUNTO DA OBRA E A OBRA ESPECÍFICA

Passo 3A - Significado da obra específica no conjunto da obra

Passo 3B - Análise literária (estilo, temas, construção literária)

Passo 3C - Exemplos concretos

MOVIMENTO 4 - DIFICULDADES/PECULIARIDADES DA

TRADUÇÃO

Passo 4A - Exemplos concretos

MOVIMENTO 5 - JUSTIFICATIVAS PARA O PROJETO

TRADUTÓRIO

Passo 5A - Descrição do projeto tradutório

Passo 5B - Contribuições teóricas

Passo 5C - Possíveis deficiências da tradução

Passo 5D - Perspectiva humilde, com ou sem pedido de desculpas.

(Carneiro 107).

${ }^{4}$ Outras fontes consultadas foram bancos de dados (Worldcat e Index translationum), e o Repertório brasileiro de língua e literatura latina: 1830-1996, de Tuffani (2006).

${ }^{5}$ Os dados completos a respeito das traduções de Virgílio estão descritos em Fernandes (2018). 
Nossa investigação identificou $37^{6}$ traduções das obras de Virgílio publicadas no Brasil entre 1808 e 2016. Em relação aos paratextos, as traduções pesquisadas apresentam grande número de produções que procuram contextualizar e explicar a obra ao leitor, tais como: estudos introdutórios, glossários, bibliografias, mapas, ilustrações, além dos prefácios e notas. Sobre os dois últimos, apuramos que 27 traduções possuem prefácios e 25 apresentam notas escritas pelos tradutores. Esses números demonstram a importância que os paratextos têm em edições de obras como as de Virgílio, pertencentes a uma civilização distante de nós no tempo e no espaço.

De acordo com a metodologia e a fundamentação teórica expostas, selecionamos excertos ${ }^{7}$ dos prefácios e notas dos tradutores para exemplificar os quatro temas mais frequentes nesses paratextos. A análise apresentada não pretende (e não poderia) ser exaustiva, pois a maioria das edições analisadas possui prefácios e uma grande quantidade de notas, por isso foi necessário selecionar os exemplos mais relevantes para o objetivo de evidenciar a reflexão que os tradutores fazem sobre o trabalho de tradução.

O tema que mais aparece nos prefácios e notas dos tradutores de Virgílio é a contextualização da obra e seu autor, constante em praticamente todas as edições. Há uma preocupação por parte dos tradutores em apresentar fatos histórico-biográficos a respeito de Virgílio e da sua época, comentar sobre suas fontes e influências, resumir e analisar literariamente a obra traduzida, contextualizá-la historicamente, bem como situá-la no conjunto das obras virgilianas. Os tradutores reiteradamente enaltecem a obra e seu autor. A importância da obra para a história da literatura é por vezes

\footnotetext{
${ }^{6}$ Após a publicação do artigo "Virgílio no Brasil” (Fernandes, 2018), encontramos duas traduções que não estavam catalogadas no acervo on-line da Biblioteca Nacional. São elas: Traduções avulsas, publicada pela Typographia Brasil em 1924, que apresenta a tradução de Estevam de Oliveira para o Canto II da Eneida; e Eneida de Públio Virgílio Maro, publicada pela Livraria Salesiana Editora, em 1952, cujo tradutor é J. C.

${ }^{7}$ Os exemplos citados tiveram o texto em português atualizado segundo a última Reforma Ortográfica.
} 
apresentada como justificativa para sua (re)tradução. Existe uma preocupação por parte dos tradutores em contextualizar e explicar o texto virgiliano, alegando que, pela distância temporal e cultural que separa o leitor dos romanos, ele teria dificuldade para compreender sua literatura, por isso é oferecido um conjunto de paratextos que tenta suprir essa barreira.

O segundo tema que recebeu atenção dos tradutores foi problemas e especificidades da tradução, que subdividimos em subtemas para melhor comparar as diferentes abordagens dos tradutores. O primeiro deles refere-se à discussão sobre como traduzir poesia, de Virgílio, ou no geral: se em prosa ou em verso. Das 37 traduções analisadas, 21 são em verso e 16 em prosa, ou seja, há uma preferência pelo verso, porém a quantidade de traduções em prosa é expressiva. Encontramos distintas opiniões a respeito dessa questão nos paratextos examinados.

Entre os defensores da tradução em verso, está Márcio Thamos, tradutor do Canto I da Eneida, que transpôs os hexâmetros virgilianos em decassílabos, "[...] buscando-se assim uma equivalência métrica expressiva entre a poética da língua latina e a da língua portuguesa [...]" (Thamos 406). Da mesma forma, Péricles Eugênio da Silva Ramos, tradutor das Bucólicas, entende que “[...] apesar das limitações que isso possa impor, um texto poético metrificado só pode traduzir-se em verso, para dar uma ideia do que seja o original." (Ramos 10).

A defesa do verso já aparece em tradutores do século XIX, como descreve Lucindo Filho, tradutor das Bucólicas: "Adotei, pois, o verso decassílabo solto, por ser o que mais se coaduna à tradução de um poeta como Virgílio, que só usara do hexâmetro, e para poder conservar fielmente o sentido e as palavras do original." (Filho, Novas virgilianas, 60). No geral, aquilo que os tradutores partidários do verso entendem como uma tradução fiel ou equivalente ${ }^{8}$ de Virgílio é uma tradução em verso português correspondente ao verso latino. Thamos e Filho, por exemplo, adotam o decassílabo.

${ }^{8}$ Os adjetivos fiel e equivalente são usados por alguns dos tradutores de Virgílio para caracterizar suas traduções.

Cad. Trad., Florianópolis, v. 41, nº 2 p. 159-179, mai-ago, 2021. 
Entre os defensores da tradução de poesia em prosa está João Nunes de Andrade, tradutor das Bucólicas: "algumas traduções, principalmente em verso, afastam-se tanto do sentido das palavras do autor, em umas partes aumentando, em outras diminuindo, alterando, desfigurando, que seus autores se a este teatro voltassem pasmariam [...]." (Andrade VII). Para esse autor, a tradução em prosa, por não ter as amarras do verso, mais se aproxima do sentido do texto. Leopoldo Pereira, tradutor da Eneida, indo ao encontro de Andrade afirma:

\begin{abstract}
Sempre pensei que os poetas da antiguidade não devem ser traduzidos em verso. Raras são as traduções poéticas que deem uma ideia aproximada do original. A medida do verso obriga frequentemente o tradutor, ora a cortar pelo texto e oprimir em forçada concisão dos pensamentos, ora a distendê-los por longas perífrases, acrescentando epítetos, imagens e circunstâncias, do que resulta afinal uma obra contrafeita e sem naturalidade, que não é original nem tradução. Mas quem precisa de recorrer a um intérprete para ter uma ideia dessas obras primas do engenho humano, quer que se lhe dê, em boa forma, o pensamento do autor e só ele, sem desenvolvimentos nem diminuições; e isto só em prosa se pode fazer. (Pereira III).
\end{abstract}

Outra especificidade da tradução de Virgílio, apresentada pelos tradutores, é a latinização de vocábulos quando não se encontram equivalentes em português. Pereira, por exemplo, em nota ao excerto do Livro VIII "[...] tudo o que se pode fazer de ferro e de fundido electro [...]", escreve: "Electrum era uma liga de ouro e prata. Adoto o termo por não haver outro em português." (Pereira 199).

Os tradutores também resgatam vocábulos antigos portugueses, pois, como Odorico Mendes escreve em nota à Eneida: "Não se pode imitar o variadíssimo estilo de Virgílio só com a pobre e acanhada linguagem dos nossos jornais; é mister empregar todos os recursos do português, e às vezes nem isto basta." (Mendes 
182). Eles também recorrem à criação de neologismos quando vocabulário português contemporâneo não dá conta de expressar o vocabulário latino. Dois tradutores do século XIX, entre outros nomes, foram exímios inventores e estabeleceram um paradigma para os seguintes: Antonio José de Lima Leitão e Odorico Mendes. Ambos já anunciam tanto a prática de resgate quanto de criação de vocabulário nos seus prefácios. Leitão escreve: “Achar-se-ão palavras com usos novos, e mesmo novas palavras. É este o método de enriquecer as línguas." (Leitão XII).

Odorico Mendes, por sua vez, afirma na Advertência à Eneida: "Adotei algumas palavras do latim e compus não poucas por me parecerem necessárias na ocasião. De algumas faço menção nas notas; de outras não tratei, por ser óbvio o sentido em que as tomo." (Mendes 32). O maranhense também explica a composição de alguns neologismos, como nesta anotação à tradução da Eneida: "No meu verso 98 usei de persentiu, que não vem nos dicionários da língua: não sei se já é nosso, mas sei que é necessário, porque exprime ideia diversa da do simples e do composto pressentir." (Mendes 114). Já na tradução das Bucólicas, ele cria um verbo a partir de um nome: "Temos lourejar; mas julguei útil flavescer, porque lourejar ficaria mui perto da consonância em ar do verso antecedente. Louro era nosso, e Camões introduziu flavo: consintam-me o verbo." (Mendes 93). Na tradução das Geórgicas, Odorico Mendes anota: “Male pinguis não é infecundo, mas pouco fértil: se o terreno areento fosse infecundo, na força do termo, não merecia ser cultivado; sendo pouco fértil, melhora-se. Imitando o latim, compus malpingue [...]." (Mendes 101), isto é, ele cria malpingue unindo um advérbio latino (male) a um adjetivo (pinguis).

Ainda sobre os neologismos, em sua tradução das Geórgicas, Leitão escreve nota sobre a formação de um verbo a partir de um adjetivo criado por Amador Arraes, escritor e religioso português do século XVI:

Transnoita sobre duras penedias - Amador Arraes diz pregando em umas partes, e outras, perseguido em todas, e 
trasnoitado em oração - Ora eu, que me cansei em buscar um verbo para exprimir o - jacet pernox - do texto, não o achei: portanto fi-lo. Se Arraes criou o adjetivo - transnoitado - da preposição trans e do nome nox latinos; eu derivo o meu verbo - transnoitar - do seu adjetivo - transnoitado - o que passou noites sem dormir: - transnoitar passar noites sem dormir. (Leitão 172).

Ainda no âmbito dos problemas e especificidades da tradução, encontramos a questão da concisão da língua latina, que é sintética, em oposição ao português, língua analítica. Recriar em português a mesma brevidade e economia da frase latina é um desejo manifestado por muitos tradutores, como Carvalho, que, nos comentários às Bucólicas, escreve que sua concepção é a "de traduzir com economia, mas sem supressão de elementos importantes [...]" (Carvalho 157). Assim como em relação aos neologismos, o modelo de concisão entre os tradutores é Odorico Mendes. Carvalho, por exemplo, declara que "Este [Valéry] me encoraja a escrever versos mais harmônicos, aquele [Odorico Mendes] me desafia a fazê-los mais concisos." (Carvalho 148). De fato, o maranhense foi capaz de traduzir a Eneida quase igualando o número de versos do original: o texto latino possui 9.901 versos e a tradução de Odorico Mendes, 9.946 . Para esse tradutor, o português apresentaria mais possibilidades em relação às outras línguas latinas nesse quesito: "Pode a nossa língua no mesmo número de versos traduzir essas belezas; o que ainda não conseguiu nenhuma das vivas, nem as duas mais suaves, a Castelhana e a Italiana." (Mendes 54). Em nota à Eneida, Odorico Mendes comenta sobre a tradução do verso Una salus victis, nullam sperare salutem: “Atente-se na vantagem que a nossa aqui leva à língua Francesa. Este verso traduziu M. Villenave: Le seul pour les vaincus est de n'attendre aucun salut;

${ }^{9} \mathrm{O}$ número de versos citado refere-se à segunda edição da Eneida, revisada e publicada por Odorico Mendes em 1858, juntamente com as traduções das Geórgicas e das Bucólicas, sob o título de Virgílio brasileiro. O número de versos da tradução da Eneida na primeira edição era de 10.042. 
eu pude dizer: A vencidos uma só esperança, o desespero. A falta de verbo que tem força no texto, admite-se em português, não em francês." (Mendes 73).

Por características próprias da língua, o francês exige o emprego do verbo, enquanto o português permite sua supressão sem prejuízo à sintaxe e ao sentido da frase. Em contrapartida, Lucindo Filho, apesar da admiração pela tradução do maranhense, critica seu modo de traduzir em prefácio:

Mas é forçoso confessar que o ilustre maranhense, na ímproba determinação de reduzir o verso latino ao português, tornou a sua, aliás, excelente tradução, muitas vezes obscura, e alatinou-a em demasia. Realmente só à custa de anfibologias poderia essa tradução ser feita sempre verso a verso, sendo a língua latina essencialmente elíptica. (Filho, Virgilianas, 7).

Antes de Odorico Mendes, Leitão também já atentava para esse assunto. No prefácio à Eneida, ele escreve: “[...] acreditava eu que o tradutor poeta devia sacrificar a harmonia à concisão; hoje porém penso que ambas devem ir a par, e modificarem-se mutuamente." (Leitão IX). Para este tradutor, portanto, a concisão não é um valor absoluto, mas deve ser buscada sempre que possível. Para o verso “Trazei-me, versos meus, trazei-me Daphnis" das Bucólicas, Leitão registra a seguinte nota:

Diz o texto: Ducite ab urbe domum, mea carmina, ducite Daphnin. Para não afrouxar o verso latino pondo-o em dois portugueses, suprimi na tradução a palavra - domum - , suprindo-a com o pronome - me -: e suprimi, sem a suprir, a palavra - $a b$ urbe -: Visto que o tudo era que Daphnis viesse do lugar onde estava longe da maga, para onde ela exercia os seus encantamentos. (Leitão 69). 
O tradutor optou por não traduzir ab urbe domum ("da cidade para casa") e acrescentar o pronome "me", inexistente em latim, para dar a ideia de que quem profere o verso deseja que Dáfnis retorne para perto de si. A solução de Leitão foi adotada por Odorico Mendes, que em nota à sua tradução diz: "Não achei forma que traduzisse tão bem como o Sr. Leitão, cujo verso adotei [...].” (Mendes 164).

Na nota citada acima, percebe-se que Odorico Mendes conhecia a tradução anterior à sua e foi influenciado por ela para solucionar um problema de tradução. Nos paratextos analisados, fica evidente que existe um diálogo entre tradutores: eles fazem elogios ou críticas uns aos outros e citam nomes de tradutores que admiram. Foi possível constatar, portanto, que os tradutores conhecem, consultam e comparam suas traduções com outras, tanto portuguesas quanto de outras línguas.

Os paratextos analisados oferecem outros de tradutores que recorreram às traduções dos colegas para resolver dificuldades. Carvalho, por exemplo, comenta sobre os problemas suscitados pelo vocabulário empregado por Virgílio nas Bucólicas e como outras traduções podem servir de auxílio:

Entre os vocabulários especiais, o de botânica é um dos mais difíceis de traduzir, porque os nomes latinos deram origem nas línguas modernas a vocábulos atribuídos a plantas diferentes. Na minha tradução, procurei não fugir do problema e segui a lição dos tradutores e comentadores consultados. (Carvalho 124).

Em outros casos, tradutores citam colegas para reprovar suas escolhas, como Odorico Mendes em notas à Eneida: "Não penso como o nosso digno compatriota o Sr. João Gualberto [...]" (Mendes 178) ou "Permita-se-me aqui notar uma falta de gosto em um dos nossos tradutores. [...] E ainda pior é o remate de João Franco [...].” (Mendes 231), excertos que evidenciam a reprovação às soluções encontradas por outros tradutores. 
Especialmente nos prefácios, os tradutores de Virgílio citam tradutores que admiram, como José Bonifácio em tradução às Bucólicas: “[...] compare o leitor esta versão com as de Leonel da Costa, Cândido Lusitano, e Malhão, e decida se perdi o meu tempo." (Silva 153). João Gualberto Ferreira Santos Reis pondera sobre as traduções de dois portugueses em seu prefácio à Eneida:

\begin{abstract}
Vi a tradução de João Franco Barreto: respeitando os vastos conhecimentos e autoridade deste tradutor e poeta, acho que em muitos lugares melhor frase, e termos melhores empregaria, (pois muito bem os conhecia) se o rigor e a necessidade da rima, a que injustamente se foi prender, o não constrangessem ao contrário. Vi também, já depois de concluída e correta a minha tradução, a do Dr. Antonio José de Lima Leitão, em que há muito ouvira falar, e muito desejava ler; e folguei de que em vários lugares achasse tão ajustadas nossas ideias e expressões, que até alguns versos já inteiramente iguais. (Reis 4).
\end{abstract}

A afirmação de Reis de que teria traduzido alguns versos "inteiramente iguais" a Leitão é controversa, mais provável é que tenha lido a tradução de Leitão e adotado algumas soluções por não encontrar outras melhores. Já Estevam de Oliveira, tradutor da Eneida, ao contrário dos outros, afirma não ter lido outras traduções: "Da Eneida não conheço tradução nenhuma, nem mesmo a de Odorico Mendes [...]. Assim, o trabalho interpretativo aqui oferecido ao leitor é exclusivamente meu." (Oliveira 127).

Há ainda um último tema recorrente nos paratextos analisados: as justificativas para o projeto de tradução. Os tradutores apresentam argumentos para a (re)tradução das obras, que na maior parte das vezes têm relação com a importância de Virgílio para a literatura Ocidental e com a qualidade da sua obra. Nessas justificativas, os tradutores exaltam Virgílio ao mesmo tempo que, a exemplo daqueles analisados por Carneiro, colocam-se em uma posição de humildade, muitas vezes pedindo desculpas por eventuais equívo- 
cos na tradução. José Bonifácio, por exemplo, escreve: "Se este meu pequeno trabalho merecer alguma aprovação, prometo publicar os outros nove idílios que restam [...]." (Silva 154). No prefácio citado mais acima, Firmino antecipa e justifica possíveis falhas em sua tradução quando escreve: "Entretendo-me e distraindo-me, somente nas horas vagas, com o hobby do Latim, à semelhança daqueles motoristas que só aos domingos conduzem os automóveis, é de presumir que haja fatalmente desastres ou erros nesta obra [...]." (Firmino 34).

Outros tradutores, por sua vez, são menos humildes. Oliveira, em seu prefácio, diz: "Se raciocinei mal, que se me apresente melhor interpretação." (Oliveira 129) e, mais adiante, "Em todas essas passagens minha preocupação era encontrar uma fórmula de linguagem contemporânea que exprimisse com exatidão, de maneira clara e compreensível, o pensamento contido no original. Se não o consegui 'faciant meliora potentes' ${ }^{10}$." (Oliveira 130). Já Leitão escreve sobre o posicionamento modesto de alguns tradutores: “Aparto-me do uso de começar os prefácios pela confissão da própria incapacidade; confissão não sincera, modéstia afetada, que leva a mira em mais se engrandecer, é melhor captar a benevolência; mas que não ilude homens sensatos.” (Leitão XI).

Diante do exposto, podemos afirmar que os tradutores de Virgílio fazem uso dos paratextos para, além de outros objetivos, tecer comentários sobre problemas e questões de tradução. Para chegar a essa consideração, analisamos o conteúdo dos prefácios e das notas das 37 traduções de Virgílio, publicadas no Brasil entre 1808 e 2016, quando escritos pelos seus respectivos tradutores. Por conta da quantidade e da variedade de questões contidas nesses paratextos, elegemos os quatro temas que mais recorreram.Selecionamos excertos dos discursos dos tradutores apresentados nos prefácios e nas notas para exemplificá-los.

No geral, a análise dos prefácios mostrou que as traduções de Virgílio são muito anotadas. Praticamente todas as traduções pes-

${ }^{10}$ Faciant meliora potentes: façam melhor os que puderem. 
quisadas apresentam algum elemento paratextual, além da grande quantidade de prefácios e notas dos tradutores. Paulo Rónai afirma que as notas dos tradutores são importantes em obras que estão "[...] distantes de nós em tempo, lugar e em espírito" (Rónai 65). Já o tradutor João Angelo Oliva Neto diz em entrevista que “[...] tradução de poesia antiga costuma ser muito anotada [...]” (Oliva Neto 264). A partir dessas afirmações e da análise empreendida, podemos inferir que o leitor desse tipo de literatura espera que a tradução venha acompanhada de paratextos, o que nos leva a pensar que ele seja, em sua maioria, um leitor especialista, que tem um interesse acadêmico (e não só de entretenimento) nesse tipo de leitura.

Sobre as notas analisadas, verificamos que a maioria tem função explicativa a respeito de nome, epítetos, topônimos e aspectos da mitologia, cultura e história romanas. Muitas notas têm um caráter semelhante ao de um glossário. Ao mesmo tempo, como a análise mostrou, há uma quantidade significativa de notas em que os tradutores comentam sobre seu processo tradutório, buscando justificar ao leitor suas escolhas, comparando as soluções adotadas com as de outros tradutores, revelando suas estratégias de tradução. Essas características corroboram a afirmação de Genette de que as notas podem ser propostas "[...] apenas a alguns leitores: aqueles a quem possa interessar determinada consideração complementar ou digressiva, cujo caráter acessório justifica exatamente a colocação em nota." (Genette 285). Esse tipo de informação mais específica sobre o processo de tradução interessa mais a um leitor especializado, com algum conhecimento da língua latina.

Ainda sobre os prefácios, Carneiro (240) entende esse elemento paratextual como uma das poucas oportunidades que o tradutor tem para comentar sobre seu trabalho. Nos prefácios analisados pela autora, esse tipo de informação pouco aparece, os tradutores preferem apresentar a obra e o autor traduzidos, em vez de expor e valorizar seu próprio trabalho. Nos prefácios de Virgílio, embora haja também esse tipo de apresentação, existe uma preocupação por parte dos tradutores em evidenciar o processo de tradução, ao contrário do que Carneiro verificou no seu corpus. 
Voltando às notas, Soto afirma em sua tese que, quando são escritas pelo tradutor, "[...] não raro são abordadas com uma postura negativa e prescritiva”, como se fossem a afirmação de que o tradutor não conseguiu resolver na tradução determinado problema: "[...] sempre há quem comente que ceder à inclusão da nota é um atestado de incompetência do tradutor" (Soto 21). Por conta da quantidade e frequência das notas nas traduções de Virgílio, podemos inferir que nas edições de literatura clássica esse elemento paratextual é mais aceito, pois o leitor espera que o texto traduzido tenha um aparato que o guie e, ao mesmo tempo, amplie sua leitura.

Ainda que não tenhamos analisado o texto das traduções, o exame dos temas recorrentes nos paratextos revelou o caráter inovador das traduções de Virgílio, especialmente daquelas publicadas no século XIX. Tradutores como Leitão e Odorico Mendes, entre outros, conforme atestam os exemplos citados, criaram neologismos e forçaram os limites da sintaxe portuguesa, com o intuito de valorizar e enriquecer a língua nacional, em uma tentativa de equipará-la à língua latina, especialmente no que diz respeito à sua concisão. Como afirma Even-Zohar, as traduções podem ser responsáveis por renovar as literaturas nacionais. Embora seja necessária uma análise mais exaustiva a respeito desse tema, é possível pensar na hipótese de que essas traduções tenham tido um papel inovador no sistema literário brasileiro.

Quando se trata da tradução de obras antigas, a questão da temporalidade em tradução se impõe: como traduzir um texto que não é mais do tempo da tradução? O tradutor, consciente desse problema, sabe que, para compreender e traduzir as manifestações literárias de uma cultura afastada, é necessário ao menos diminuir a distância que nos separa. Após a conclusão deste estudo, podemos afirmar que, no caso específico das traduções de Virgílio, os paratextos são uma estratégia fundamental para aproximar o leitor da obra traduzida. Além disso, as notas e prefácios também se configuram como um espaço de visibilidade dos tradutores quando exploram as diversas facetas do seu trabalho de tradução. 


\section{Referências}

Andrade, João Nunes de. "Prefácio e notas à tradução". Tradução das Bucólicas: diálogo pastoril de Virgílio. Tradução de João Nunes de Andrade, Virgílio. Rio de Janeiro: Typ. Brasilense de F. M. Ferreira, 1846.

Carneiro, Teresa Dias. Contribuições para uma teoria do paratexto do livro traduzido: caso das traduções de obras literárias francesas no Brasil a partir de meados do século XX. 2014. 398 f. Tese (Doutorado) - Programa de Pósgraduação em Estudos da Linguagem, Pontifícia Universidade Católica do Rio de Janeiro, Rio de Janeiro, 2014. Maxwell PUC-Rio. 22/03/2020. https://www. maxwell.vrac.puc-rio.br/29928/29928.pdf.

Carvalho, Raimundo de. "Prefácio e notas à tradução". Bucólicas. Tradução de Raimundo de Carvalho e Manuel Odorico Mendes (em apêndice), Virgílio. Belo Horizonte: Crisálida, 2005.

Duarte, Adriana da Silva. "Por uma história da tradução dos clássicos grecolatinos no Brasil”. Translatio. 12 (2016): 43-62. Portal de Periódicos da UFRGS. 10/04/2020. < https://seer.ufrgs.br/translatio/article/view/69211/39854>.

Even-Zohar, Itamar. “Polysystem studies”. Poetics today, 11. 11990.

Fernandes, T. "Virgílio no Brasil". Belas Infiéis. 7.1 (2018): 351-373. Portal de Periódicos da UnB. 10/02/2020. < https://doi.org/10.26512/belasinfieis. v7.n1.2018.12579>.

Filho, Lucindo. Novas virgilianas. Vassouras: Typ. do Vassourense, 1888.

Filho, Lucindo. Virgilianas. Vassouras: Typ. do Vassourense, 1883.

Firmino, Nicolau. "Prefácio e notas à tradução". As abelhas: versão da $4^{a}$ Geórgica. Tradução de Nicolau Firmino. Virgílio. Rio de Janeiro: H. Antunes, 1966. 
Genette, Gérard. Paratextos Editoriais. Tradução de Álvaro Faleiros. Cotia: Ateliê Editorial, 2009.

Hallewell, Laurence. O livro no Brasil: sua história. Tradução de Maria da Penha Villalobos, Lólio Lourenço de Oliveira e Geraldo Gerson de Souza. 3. ed. São Paulo: EDUSP, 2012.

Leitão, Antonio José de Lima. "Prefácio e notas à tradução". Monumento à elevação da colônia Brasil a Reino, e ao estabelecimento do tríplice Império Luso. As obras de Públio Virgílio Maro, traduzidas em verso português, e anotadas pelo Doutor Antonio José de Lima Leitão. Tradução de Antonio José de Lima Leitão, Virgílio. Rio de Janeiro: Typographia Real, [entre 1818 e 1819]. 3 t.

Mendes, Manuel Odorico. "Prefácio e notas à tradução". Bucólicas. Tradução Manuel Odorico Mendes. Edição anotada e comentada pelo Grupo de Trabalho Odorico Mendes, Virgílio. Cotia: Ateliê Editorial; Campinas: Editora da UNICAMP, 2008.

Mendes, Manuel Odorico. "Prefácio e notas à tradução". Eneida. Tradução e notas de Manuel Odorico Mendes. Apresentação de Antonio Medina. Estabelecimento do texto, notas e glossário de Luiz Alberto Machado Cabral, Virgílio. Cotia: Ateliê Editorial; Campinas: Editora da Unicamp, 2005.

Mendes, Manuel Odorico. "Prefácio e notas à tradução". Virgílio brasileiro. Tradução de Manuel Odorico Mendes, Virgílio. Paris: Typographia de W. Remquet, 1858.

Oliva Neto, João Ângelo. "Entrevista com João Ângelo Oliva Neto". Cadernos de Tradução. 1.25 (2010). Portal de Periódicos da UFSC. 10/03/2020. < https://periodicos.ufsc.br/index.php/traducao/article/view/21757968.2010v1n25p261/13970>.

Oliveira, Estevam. "Prefácio e notas à tradução". Traduções avulsas (Cícero, Virgílio, Horácio e Tito Livio). Tradução de Estevam de Oliveira, Cícero et. al. Juiz de Fora: Typographia Brasil, 1924.

Pereira, Leopoldo. "Prefácio e notas à tradução". Eneida. Tradução de Leopoldo Pereira, Virgílio. Belo Horizonte: Imprensa Official do Estado de Minas, 1920. 
Pinilla, José Antonio Sabio. A metodologia em história da tradução: estado da questão. Tradução de Martha Lucía Pulido Correa et al. Belas Infiéis. 6.2 (2017): 223-255. Portal de Periódicos da UnB. 30/03/2018.<http://periodicos.unb.br/ index.php/belasinfieis/article/view/28271>.

Ramos, Péricles Eugênio da Silva. "Prefácio e notas à tradução". Bucólicas. Tradução de Péricles Eugênio da Silva Ramos, Virgílio. São Paulo: Melhoramentos; Brasília: Editora Universidade de Brasília, 1982.

Reis, João Gualberto Ferreira Santos. "Prefácio e notas à tradução". Ao Senhor D. Pedro II, imperador Constitucional e defensor perpétuo do Brasil. Tradução da Eneida de Públio Virgílio Marão D.O.C. em testemunho de respeito, de amor e de gratidão pelo tradutor João Gualberto Ferreira Santos Reis. Tradução de João Gualberto Ferreira Santos Reis, Virgílio. Bahia: Typographia de Galdino José Bizerra e Companhia, 1845.

Rónai, Paulo. A tradução vivida. Rio de Janeiro: Educom, 1976.

Silva, José Bonifácio de Andrada e. Poesias avulsas de Américo Elísio. Bordeaux: [s.n.], 1825.

Soto, Pablo Cardelino. Notas do tradutor em uma tradução comentada e anotada de Casa Velha, de Machado de Assis, para o espanhol. 2017. 262 f. Tese (Doutorado) - Curso de Pós-graduação em Estudos da Tradução, Centro de Comunicação e Expressão, Universidade Federal de Santa Catarina, Florianópolis, 2017. Repositório UFSC. 16/05/2020. < http:tcde.ufsc.br/teses/PGET0336-T.pdf>.

Sousa, Germana Henriques Pereira de. "Prefácio". Traduzir o Brasil literário, Marie-Hélène Catherine Torres. Tubarão: Copiart, 2011, 11-14.

Thamos, Márcio. As armas e o varão: leitura e tradução do Canto I da Eneida. São Paulo: Editora da Universidade de São Paulo, 2011.

Torres, Marie-Hélène Catherine. "Democratização de arquivos em bibliotecas digitais e hemerotecas: um caminho para Histórias ou Micro Histórias da tradução no Brasil”. Cadernos de Tradução, Florianópolis, 40.1 (2020): 208-224. Portal de Periódicos da UFSC. 09/06/2020. < https://periodicos.ufsc.br/index.php/ traducao/article/view/2175-7968.2020v40n1p208/42366>. 
Trevizam, Matheus. "Prefácio e notas à tradução". Geórgicas I. Organização: Matheus Trevizam. Traduções de Matheus Trevizam e Antonio Feliciano de Castilho, Virgílio. Belo Horizonte: Editora UFMG, 2013.

Tuffani, Eduardo. Repertório brasileiro de língua e literatura latina: 1830-1996. Cotia: Íbis, 2006.

Venuti, Lawrence. The translator's invisibility: a history of translation. London: Routledge, 1995.

Venuti, Lawrence. "A invisibilidade do tradutor”. Tradução de Carolina Alfaro. Palavra. 3.1 (1995): 111-134.

Recebido em: 30/11/2020 Aceito em: 09/02/2021 Publicado em maio de 2021

Thaís Fernandes. E-mail: fernandes.tha@gmail.com. ORCID: https://orcid. org/0000-0002-7971-094X. 